\title{
MANAJEMEN PENILAIAN KINERJA KEPALA MADRASAH (PKKM) DALAM KOMPONEN USAHA PENGEMBANGAN MADRASAH
}

\author{
(Studi kasus di Madrasah Ibtidaiyah (MI) Al-Hikmah Cibeusi Jatinangor Sumedang)
}

\author{
Erwin Feriyanto \\ UNINUS \\ erwin.feri@gmail.com
}

\begin{abstract}
The general purpose of this study was to obtain an overview and analyze the Performance Assessment Management of Madrasah Principals (PKKM) on the components of madrasah development efforts at Madrasah Ibtidaiyah (MI) Al-Hikmah Jatinangor Sumedang. The specific purpose of this research is to find out and analyze about: 1).Planning 2). Organizing 3). Implementation 4). Supervision 5). Supporting and inhibiting factors of Madrasah Principal Performance Assessment (PKKM) in the madrasa development business component at Madrasah Ibtidaiyah (MI) Al-Hikmah Jatinangor Sumedang. This study uses a qualitative research with a descriptive approach. Data collection techniques through observation, interviews and documentation studies. The theory in this research is George Terry's Management theory. The results of the research 1) Planning for Performance Assessment of Madrasah Principals (PKKM) on the madrasa development business component at Madrasah Ibtidaiyah (MI) Al-Hikmah Jatinangor Sumedang has been carried out well. 2) Organizing the Madrasah Principal Performance Assessment (PKKM) on the madrasah development business component at Madrasah Ibtidaiyah (MI) Al-Hikmah Jatinangor Sumedang has been carried out. 3) Implementation of the Madrasah Principal Performance Assessment (PKKM) on the madrasah development business component in Madrasah Ibtidaiyah (MI) Al-Hikmah Jatinangor Sumedang has been implemented. 4) Supervision of Madrasah Principal Performance Assessment (PKKM) in the madrasa development business component at Madrasah Ibtidaiyah (MI) AlHikmah Jatinangor Sumedang has not been maximally carried out by supervisors. 5) The supporting factor for PKKM is good coordination between teachers so that there is a solid work culture if there are things that need to be done, we work together to solve them and the inhibiting factor is the limited information about PKKM.
\end{abstract}

Keywords: Performance Assessment, Head of Madrasah

\begin{abstract}
Abstrak
Tujuan umum penelitian ini adalah untuk memperoleh gambaran dan menganalisis tentang Manajemen Penilaian Kinerja Kepala Madrasah (PKKM) pada komponen usaha pengembangan madrasah di Madrasah Ibtidaiyah (MI) Al-Hikmah Jatinangor Sumedang. Tujuan khusus dari penelitian ini untuk mengetahui dan menganalisis tentang: 1).Perencanaan 2). Pengorganisasian 3).Pelaksanaan 4).Pengawasan 5). Faktor pendukung dan penghambat Penilaian Kinerja Kepala Madrasah (PKKM) pada komponen usaha pengembangan madrasah di Madrasah Ibtidaiyah (MI) Al-Hikmah Jatinangor Sumedang. Penelitian ini menggunakan penelitian kualitatif dengan pendekatan deskriptif. Teknik pengumpulan data melalui observasi, wawancara dan studi dokumentasi. Teori dalam penelitian ini adalah teori Manajemen George Terry. Adapun Hasil Penelitiaanya 1).Perencanaan Penilaian Kinerja Kepala Madrasah (PKKM) pada
\end{abstract}


komponen usaha pengembangan madrasah di Madrasah Ibtidaiyah (MI) Al-Hikmah Jatinangor Sumedang sudah dilaksanakan dengan baik. 2). Pengorganisasian Penilaian Kinerja Kepala Madrasah (PKKM) pada komponen usaha pengembangan madrasah di Madrasah Ibtidaiyah (MI) Al-Hikmah Jatinangor Sumedang telah dilaksanakan.3). Pelaksanaan Penilaian Kinerja Kepala Madrasah (PKKM) pada komponen usaha pengembangan madrasah di Madrasah Ibtidaiyah (MI) Al-Hikmah Jatinangor Sumedang telah dilaksanakan. 4). Pengawasan Penilaian Kinerja Kepala Madrasah (PKKM) pada komponen usaha pengembangan madrasah di Madrasah Ibtidaiyah (MI) Al-Hikmah Jatinangor Sumedang belum maksimal dilakukan oleh pengawas. 5). Faktor pendukung PKKM adalah koordinasi yang baik antar guru-guru sehingga budaya kerja yang solid jika ada hal-hal yang perlu dikerjakan, kami bergotong royong untuk menyelesaikannya dan faktor penghambatnya adalah terbatasnya informasi tentang PKKM.

Kata Kunci: Penilaian Kinerja, Kepala Madrasah

Selain itu, untuk madrasah di bawah

\section{Pendahuluan}

Berdasarkan Permendiknas No. 13 Tahun 2007 tentang Standar Kepala Sekolah / Madrasah dan Permendiknas No. 28 Tahun 2010 tentang Penugasan guru sebagai Kepala Sekolah/Madrasah, Pasal 12 menyatakan bahwa:

(1)

$\begin{array}{lll}\text { Penilaian kinerja } & \text { kepala } \\ \text { sekolah/madrasah } & \text { dilakukan } & \text { secara }\end{array}$
berkala setiap tahun dan secara kumulatif setiap empat tahun;

(2) Penilaian kinerja tahunan dilakukan oleh pengawas sekolah/madrasah;

(3) Penilaian kinerja empat tahunan dilaksanakan oleh atasan langsung dengan mempertimbangkan penilaian kinerja oleh tim penilaian dari pengawas sekolah/madrasah, pendidik, tenaga pendidik, dan komite sekolah/madrasah dari tempat bertugas;

(4) Hasil penilaian kinerja dikategorikan dalam tingkatan amat baik, baik, cukup, sedang atau kurang. naungan Kementerian Agama juga terdapat

Surat Keputusan Direktur Jenderal Pendidikan Islam Kemenag Nomor 1111 Tahun 2019 berisi implementasi PMA Nomor 24 Tahun 2018 tentang Kepala Madrasah, yang merupakan regulasi terbaru Peraturan Menteri Agama tentang Perubahan atas PMA No. 58 Tahun 2017 tentang Kepala Madrasah mensyaratkan adanya Penilaian Kinerja Kepala Madrasah (PKKM). Berdasarkan peraturan tersebut dinyatakan bahwa Penilaian Kinerja Kepala Madrasah (PKKM) merupakan proses pengumpulan, pengolahan, analisis dan interpretasi data yang dikerjakan oleh kepala madrasah pada setiap indikator pemenuhan standar.

Menurut Manduku (2016: 14): "Penilaian kinerja merupakan bagian dari sistem manajemen kinerja yang diakui para ahli manajemen sebagai langkah awal peningkatan sumberdaya manusia”. 
Selain itu, menurut Kermally (1997):

"Penilaian kinerja berfungsi sebagai dasar untuk memodifikasi perilaku untuk mewujudkan kebiasaan kerja yang efektif; memberikan umpan balik yang memadai kepada setiap karyawan atas kinerjanya; dan untuk memberikan kepada manajer beberapa data untuk mengevaluasi tugasnya di masa mendatang dan menentukan kompensasi"

Dalam dunia pendidikan, penilaian kinerja dikaitkan dengan sumber daya yang paling utama, yaitu kepala sekolah/madrasah dan guru, karena merekalah sumber daya paling strategis untuk menentukan keberhasilan pendidikan. Oleh sebab itu, menurut Holi (2012:199): "Penilaian kinerja digunakan dalam bidang pendidikan untuk menjamin kualitas kinerja guru atau tenaga kependidikan, sebab semua organisasi memiliki tanggung jawab penuh atas pelayanannya terhadap pelanggan, termasuk organisasi pendidikan yang memiliki tugas untuk memberikan pelayanan terbaik kepada siswa dan orang tua, termasuk madrasah yang dalam hal ini dikelola oleh Kementrian Agama.

Selanjutnya, idealnya sekolah atau madrasah melakukan kegiatan monitoring, evaluasi, dan pelaporan pelaksanaan program atau kegiatan sekolah dengan prosedur yang tepat, serta merencanakan tindak lanjutnya. Program atau kegiatan sekolah tersebut dilakukan madrasah di bawah kendali kepala madrasah yang merupakan level manajemen puncak di madrasah.

Menurut Rosmiati dan Kurniady (2008:125) menyebutkan bahwa pada level manajemen puncak kemampuan di dalam melihat sesuatu secara keseluruhan yang kemudian dapat merumuskannya, seperti dalam mengambil keputusan, menentukan kebijakan, dan lain-lain. Dalam hubungan ini, perlu ditekankan bahwa seorang pemimpin (karena level manajemen puncak merupakan pimpinan) yang baik, adalah pemimpin yang tidak melaksanakan sendiri tindakan-tindakan yang bersifat operasional. Lebih banyak merumuskan konsep-konsep. Keterampilan ini ada juga yang menyebut dengan managerial skill.

Purwanto (2009:160) mengemukakan bahwa sistem persekolahan di Indonesia pada umumnya kepala sekolah merupakan jabatan yang tertinggi di sekolah sehingga dengan demikian kepala sekolah memegang peranan dan pimpinan segala sesuatu yang berhubungan dengan tugas sekolah ke dalam maupun ke luar. Maka dari itu, dalam struktur organisasi sekolah pun kepala sekolah biasanya selalu didudukkan di tempat paling atas. Untuk menghasilkan kepala sekolah yang mampu menjalankan fungsinya dengan baik dibutuhkan guru yang profesional, sebab jabatan kepala 
sekolah merupakan tugas tambahan sampai saat ini banyak upaya untuk meningkatkan kemampuan profesional guru, tetapi upaya meningkatkan mutu pembelajaran sering menemui kendala.

Unicef (2007:189) menengarai bahwa salah satu kegiatan sebagai wujud upaya perbaikan di atas, yaitu melalui sistem pembinaan profesional, pembentukan gugus sekolah, dan pembinaan profesional di masing-masing sekolah. Setiap gugus SD/MI dibentuk Kelompok Kegiatan Kepala Sekolah (KKKS) dan Kelompok Kerja Guru (KKG). Walaupun gugus sekolah sudah dibentuk dan kegiatan kelompok kerja guru melalui KKKS, KKG dan MGMP telah berjalan, namun pelaksanaan kegiatan ini sering kurang memadai sebagai forum untuk meningkatkan mutu pembelajaran di sekolah.

Kurang memadainya keefektifan forum-forum di atas salah satu penyebabnya yaitu pelaksanaan monitoring, evaluasi, dan pelaporan yang semestinya merupakan bagian tidak terpisahkan dari kinerja manajerial kepala sekolah kurang berjalan optimal. Tentu saja kompetensi manajerial kepala sekolah (Peraturan Menteri Pendidikan Nasional Nomor 13 Tahun 2007) tersebut menjadi landasan untuk mengelola komponen-komponen dalam pendidikan. Karena berupa kompetensi dan dilaksanakan melalui kegiatan manajemen sekolah, maka keberadaannya dapat dilakukan evaluasi dengan melakukan penilaian kinerja manajerial kepala sekolah. Penilaian kinerja manajerial kepala sekolah sesuai dengan Peraturan Menteri Pendidikan Nasional No 28 Tahun 2010.

Penilaian kinerja kepala sekolah/ madrasah dilakukan secara berkala setiap tahun dan secara kumulatif setiap empat tahun. Penilaian kinerja tahunan dilaksanakan oleh pengawas sekolah. Penilaian kinerja empat tahunan dilaksanakan oleh atasan langsung dengan mempertimbangkan penilaian kinerja oleh tim penilai yang terdiri dari pengawas sekolah, guru, tenaga kependidikan, dan komite sekolah di mana yang bersangkutan bertugas. Penilaian kinerja kepala madrasah meliputi: (1) Usaha pengembangan madrasah (2) Pelaksanaan tugas managerial, (3) Pengembangan kewirausahaan, (4) Supervisi kepada guru dan tenaga kependidikan dan (5) Hasil kinerja kepala madrasah.

Pada penelitian ini, peneliti hanya fokus terhadap PKKM pada komponen usaha pengembangan madrasah, karena pendidikan di madrasah tidak hanya mengarah kepada keunggulan akademis (academic excellence), tetapi justru menegaskan orientasi pembentukan 
karakter (character building) yang berasaskan prinsip akhlakul karimah. Madrasah sebagai lembaga pengembangan dakwah, dengan sendirinya menjadi salah satu tanda syiar agama sekaligus tampil sebagai komponen penting dari gerakan amar ma'ruf nahi munkar. Sebagai lembaga pendidikan masyarakat, madrasah berperan dalam pengembangan masyarakat sekitar (stakeholders) terutama terkait dengan masalah keagamaan maupun pemberdayaan sektor nonkeagamaan.

Dengan demikian, madrasah merupakan pendidikan berbasis masyarakat (community based education). Peran aktif madrasah dalam pemberdayaan masyarakat sekitar dan sebaliknya peran aktif masyarakat dalam pengembangan madrasah akan menjadi amat penting, sehingga satu sama lain saling mendukung dalam meraih kemanfaatan dan kemaslahatan bersama (mutual support for the sake of mutual benefit).

Dalam konteks itulah, pengembangan madrasah tidak dapat ditangani secara parsial atau setengah-setengah, tetapi memerlukan pemikiran pengembangan yang utuh dan komprehensif serta langkah dan upaya yang visibel, fleksibel, dan kredibel, terutama ketika dihadapkan pada kebijakan pembangunan nasional bidang pendidikan yang mempunyai visi terwujudnya sistem pendidikan sebagai pranata sosial yang kuat dan berwibawa untuk memberdayakan semua warga negara Indonesia berkembang menjadi manusia yang berkualitas, sehingga mampu dan proaktif menjawab tantangan zaman yang selalu berubah.

Ditambah lagi era globalisasi telah memberi dampak yang cukup luas dalam berbagai aspek kehidupan, termasuk tuntutan mutu dalam penyelengaraan pendidikan. Pada era ini setiap bidang menuntut SDM bermutu yang memiliki kemampuan tinggi, handal, dan kompetitif. Untuk memenuhi tuntutan ini, perbaikan dan pengembangan sistem penyelenggaraan pendidikan di madrasah secara berkesinambungan perlu dilakukan sejalan dengan dinamika perkembangan ilmu pengetahuan dan teknologi serta dinamika perubahan masyarakat itu sendiri.

Penguatan keunggulan madrasah tersebut dengan cara membangun cita-cita dan kultur akademik yang kokoh hingga memunculkan output yang unggul dan baik sesuai harapan masyarakat. Oleh sebab itu, maka peneliti, ingin mengetahui Manajemen Penilaian Kinerja Kepala Madrasah (PKKM) berdasarkan indikatorindikator usaha pengembangan madrasah yang telah ditetapkan dalam Juknis PKKM Surat Keputusan Direktur Jenderal Pendidikan Islam Kemenag Nomor 1111 Tahun 2019 di Madrasah 
Ibtidaiyah (MI) Al-Hikmah Jatinangor Sumedang, karena sebagai MI yang sudah berdiri sejak tahun 1971, lembaga ini mampu mengikuti perkembangan zaman di tengah persaingan lembaga-lembaga baru yang bermunculan dibuktikan dengan nilai Akreditasi A sejak tahun 2010 dengan jumlah siswa yang selalui meningkat setiap tahunnya dan lulusan yang mayoritas masuk ke jenjang yang lebih tinggi.Tentunya peran Kepala Madrasah dalam pengembangan madrasah sangat berpengaruh apalagi dengan adanya PKKM bisa diketahui usaha pengembangannya.

\section{Metode}

Berdasarkan permasalahan dan tujuan penelitian, maka penelitian ini dilaksanakan dengan menggunakan penelitian kualitatif. Penelitian ini menggunakan pendekatan kualitatif karena peneliti ingin mengetahui secara menyeluruh mengenai Manajemen Penilaian Kinerja Kepala Madrasah (PKKM) dalam Usaha Pengembangan Madrasah, peneliti memilih MI Al-Hikmah Jatinangor Sumedang), yang terdiri atas perencanaan, pengorganisasian, pelaksanaan dan pengawasan PKKM ditambah factor pendukung dan penghambatnya.

\section{Hasil dan Pembahasan}

\section{Perencanaan Penilaian Kinerja}

Kepala Madrasah (PKKM) pada komponen usaha pengembangan madrasah di Madrasah Ibtidaiyah (MI) Al-Hikmah Jatinangor Sumedang.

Berdasarkan hasil temuan dan interpretasi, perencanaan PKKM pada komponen usaha pengembangan madrasah di Madrasah Ibtidaiyah (MI) Al- Hikmah Jatinangor Sumedang adalah sebagai berikut:

PKKM merupakan bagian dari sistem peningkatan mutu profesi kepala madrasah secara utuh dan menyeluruh. Hal yang pertama dilakukan adalah Penilaian Kinerja Awal Tahun atau disebut juga dengan penilain diri, yaitu penilaian yang dilakukan oleh kepala madrasah sendiri dengan menggunakan instrumen PKKM. Hal ini sesuai dengan pendapat Terry dalam Hasibuan (2017).

"Planning is the selecting and relating of facts and the making and using of assumptions regarding the future in the visualization and formulation to propose of proposed activation believed necesarry to accieve desired result".

(Perencanaan adalah memilih dan menghubungkan fakta dan membuat serta dan menggunaan asumsi-asumsi mengenai masa yang akan datang dengan jalan menggambarkan dan merumuskan kegiatan-kegiatan yang diperlukan untuk mencapai hasil yang diinginkan). 
Penilaian diri yang dilakukan oleh Kepala Madrasah dengan menggunakan instrument PKKM merupakan kegiatan untuk menilai pengelolaan yang dilakukan oleh kepala madrasah, sehingga dapat melangkah ke tahap PKKM berikutnya. Hal ini dilaksanakan untuk mengetahui kekuatan dan kelemahan kepala madrasah.. Hasil penilaian diri disampaikan kepada pengawas pembina MI Kecamatan Jatinangor untuk diperiksa, selain itu juga digunakan oleh kepala madrasah untuk menyusun program pengembangan keprofesian berkelanjutan.

Instrumen Penilaian Kinerja Akhir Tahun yang dilakukan dengan menggunakan instrumen penilaian kinerja kepala madrasah yang terdiri dari 4 komponen, yaitu:
a. Usaha pengembangan madrasah
b. Pelaksanaan tugas manajerial
c. Pengembangan kewirausahaan
d. Pengawasan kepada guru dan tenaga kependidikan.

Pada tahap perencanaan PKKM kepala MI Al-Hikmah Cibeusi mempersiapkan data dan kelengkapan yang diperlukan untuk melengkapi bukti yang dibutuhkan oleh tim penilai. Instrumen PKKM diketahui berdasarkan pemberitahuan jadwal pelaksanaan PKKM 3 bulan sebelum pelaksanaan PKKM. Hal ini sesuai dengan pendapat Ya'qub, H (1984) fungsifungsi perencanaan antara lain:

"Menentukan titik tolak dan tujuan usaha; memberikan pedoman, pegangan dan arah; mencegah pemborosan waktu; memudahkan pengawasan; memungkinkan evaluasi yang teratur; sebagai alat koordinasi”.

Kepala Madrasah telah mengeluarkan Surat Keputusan tentang penetapan penanggung jawab pada setiap komponen. Penanggung Jawab tiap komponen bertanggung jawab dalam menyiapkan seluruh bukti fisik yang berada di ranahnya masing-masing. Hal ini sesuai prinsipprinsip perencanaan menurut Ya'qub, H (1984), yaitu:
a. Perencanaan harus betul-betul membantu tercapainya tujuan manajemen.

b. Perencanaan merupakan kegiatan pertama dari seluruh proses manajemen; dalam perencanaan harus selalu ada alternative baik menyangkut bahan, waktu, tenaga kerja, biaya dan sebagainya;

c. Perencanaan harus mempunyai nilainilai efisiensi, perencanaan harus fleksibel; perencanaan harus mempunyai strategi untu dapat diterima oleh semua pihak.

Para penanggungjawab melakukan koordinasi tidak hanya bersama rekannya dalam satu aspek kompetensi, namun 
mereka juga melakukan koordinasi lintas penanggungjawab dan pada bidang-bidang lain termasuk Tata Usaha. Hal ini dilakukan agar terhindar dari kegagalan perencanaan Kegagalan perencanaan menurut Ya'qub, $\mathrm{H}$ (1984) antara lain: dapat terjadi jika: perencanaan keliru, pembiayaan, pelaksanan tidak mampu dan tidak didukung oleh masyarakat.

Dalam komponen usaha pengembangan madrasah kepala madrasah menyiapkan perangkat administrasi PKKM dibantu oleh guruguru dan dibagi menjadi 4 kelompok sesuai dengan komponen PKKMnya. Hal ini sesuai dengan ciri-ciri rencana yang baik, menurut Ya'qub, H (1984) yaitu: dinamis (dipersiapkan untuk peningkatan, perbaikan dalam mencapai kemajuan), akurat (perencanaan terperinci dimuskan organisasi dalam segala aspek) dan sistematik (susunannya teratur baik).

Indikator penilaian komponen usaha pengembangan dijabarkan menjadi 7 unsur utama, kemudian unsur tugas utama tersebut dijabarkan menjadi 25 indikator kinerja. Agar mempermudah dalam menyiapkan data, maka kepala madrasah dibantu oleh kelompok 1 (tim komponen usaha pengembangan madrasah) mempersiapkan data-data dan bukti fisik berdasarkan pembagian unsur tugas utamanya, hal ini sesuai dengan pendapat
Andrew E. Sikula dalam dalam Mangkunegara (2017)

"Human resource of manpower planning has been defined as the process of determining manpower requirement and the means for meeting those requirements in order to carry out integrated plans of the organization. (Perencanaan sumber daya manusia atau perencanaan tenaga kerja didefinisikan sebagai proses menentukan kebutuhan tenaga kerja dan berarti mempertemukan kebutuhan tersebut agar pelaksanaannya berintegrasi dengan rencana organisasi).

Selain itu juga selaras dengan Hasibuan (2017)

\begin{abstract}
"Perencanaan sumber daya manusia adalah merencanakan tenaga kerja agar sesuai dengan kebutuhan perusahaan secara efektif dan efisien dalam membantu terwujudnya tujuan". Berdasarkan uraian tersebut dapat disimpulkan bahwa perencanaan PKKM pada komponen usaha pengembangan madrasah di Madrasah Ibtidaiyah (MI) Al- Hikmah Jatinangor Sumedang sudah dilakukan dengan baik.
\end{abstract}

\section{Pengorganisasian Penilaian Kinerja} Kepala Madrasah (PKKM) pada komponen usaha pengembangan madrasah di Madrasah Ibtidaiyah (MI) Al-Hikmah Jatinangor

\section{Sumedang}

Kepala Madrasah telah mengeluarkan Surat Keputusan tentang penetapan penanggung jawab pada setiap komponen. Penanggung Jawab tiap komponen 
bertanggung jawab dalam menyiapkan seluruh bukti fisik yang berada di ranahnya masing-masing. Hal ini sesuai dengan pendapat Terry dalam Sukarna (2011: 38) mengemukakan tentang organizing sebagai berikut, yaitu:

Various activities needed necessary for the attainment of the objectives, the assigning of the people to the sent activities, the providing of suitable physical factors of environment and the indicating of the relative authority delegated to each respective activity. (Pengorganisasian ialah penentuan, pengelompokkan, dan penyusunan macam-macam kegiatan yang dipeelukan untuk mencapai tujuan, penempatan orang-orang (pegawai), terhadap kegiatan-kegiatan ini, penyediaan faktor-faktor fisik yang cocok bagi keperluan kerja dan penunjukkan hubungan wewenang, yang dilimpahkan terhadap setiap orang dalam hubungannya dengan pelaksanaan setiap kegiatan yang diharapkan)

Para penanggungjawab melakukan koordinasi tidak hanya bersama rekannya dalam satu aspek kompetensi, namun mereka juga melakukan koordinasi lintas penanggungjawab dan pada bidang-bidang lain termasuk Tata Usaha. Hal ini dilakukan agar terhindar dari kegagalan perencanaan Kegagalan perencanaan menurut Ya'qub, $\mathrm{H}$ (1984) antara lain: dapat terjadi jika: perencanaan keliru, pembiayaan, pelaksanan tidak mampu dan tidak didukung oleh masyarakat.
Dalam komponen usaha pengembangan madrasah kepala madrasah menyiapkan perangkat administrasi PKKM dibantu oleh guruguru dan dibagi menjadi 4 kelompok sesuai dengan komponen PKKMnya. Hal ini sesuai dengan ciri-ciri rencana yang baik, menurut Ya'qub, $\mathrm{H}$ (1984) yaitu: dinamis (dipersiapkan untuk peningkatan, perbaikan dalam mencapai kemajuan), akurat (perencanaan terperinci dimuskan organisasi dalam segala aspek) dan sistematik (susunannya teratur baik).

\section{Pelaksanaan Penilaian Kinerja Kepala Madrasah (PKKM) pada komponen usaha pengembangan madrasah di Madrasah Ibtidaiyah} (MI) Al-Hikmah Jatinangor Sumedang.

Berdasarkan hasil temuan dan interpretasi, pelaksanaan PKKM pada komponen usaha pengembangan madrasah di Madrasah Ibtidaiyah (MI) Al- Hikmah Jatinangor Sumedang adalah sebagai berikut: Kegiatan PKKM ini dimulai pada pukul 07.45 WIB sampai 16.00 WIB.

Dalam kegiatan PKKM dimulai dengan pembukaan oleh Dede Syarif, S.Pd selaku pembawa acara, dilanjutkan sambutan dari Samingan, S.Pd., M.A selaku Tim Penilai PKKM. Dalam penilaian tahunan yang dilakukan pengawas di madrasah, ada 4 komponen penilaian yang dilakukan, yaitu 
usaha pengembangan madrasah, pelaksanaan tugas manajerial, pengembangan kewirausahaan dan supervisi kepada guru dan tenaga kependidikan.

Hal ini sesuai dengan Petunjuk Teknis Penilaian Kinerja Kepala Madrasah. PKKM merupakan proses pengumpulan, pengolahan, analisis dan interpretasi data yang dikerjakan oleh kepala madrasah pada setiap indicator pemenuhan standar. Indikator-indikator tersebut dikembangkan dalam pelaksanaan tugas kepala madrasah dalam 5 (lima) unsur utama, yaitu:

a. Usaha pengembangan madrasah,

b. Pelaksanaan tugas manajerial,

c. Pengembangan kewirausahaan,

d. Pelaksanaan supervisi kepada guru dan tenaga kependidikan) dan

e. Hasil kinerja kepala madrasah.

Kepala Madrasah dalam sambutannya, menyambut baik pelaksanaan Penilaian Kinerja Kepala Madrasah di MI Al-Hikmah Cibeusi. Selain itu juga beliau meminta masukan dan arahan kepada Tim setelah pelaksanaan penilaian sebagai catatan untuk mempersiapkan PKKM perempat tahun. Hal ini sesuai dengan pendapat George R. Terry dalam Sukarna (2011) bahwa:

"Actuating is setting all members of the group to want to achieve and to strike to achieve the objective willingly and keeping with the managerial planning and organizing efforts. (Penggerakan adalah membangkitkan dan mendorong semua anggota kelompok agar supaya berkehendak dan berusaha dengan keras untuk mencapai tujuan serta serasi dengan perencanaan dan usahausaha pengorganisasian dari pihak pimpinan).

Kemudian dilanjutkan presentasi Laporan Kinerja secara umum oleh kepala MI. Setelah presentasi, dilanjutkan dengan wawancara, observasi dan verifikasi dokumen oleh tim penilai PKKM. Hal ini dilakukan sesuai denga tujuan PKKM dalam Petunjuk Teknis Penilaian Kinerja Kepala Madrasah.

Dalam presentasi yang disampaikan Nenoh, M.Pd ini menyampaikan beberapa hal, diantaranya tentang program Inovasi MI AlHikmah Cibeusiyang sudah dilaksanakan, diantaranya: (1) Penguatan Budaya Lokal, (2) Memberikan Ruang Luas Siswa Berprestasi Sesuai Bakat Minat. Sedangkan aspek dalam PKKM adalah (1) Usaha Pengembangan Madrasah, (2) Pelaksanaan Tugas Manajerial, (3) Pengembangan Kewirausahaan,

Supervisi kepada Guru dan Tenaga Kependidikan dan (5) Hasil Kinerja Kepala Madrasah. Hal ini sesuai dengan pengertian Kinerja Kepala Madrasah merupakan kemampuan untuk melaksanakan pekerjaan atau tugas yang dimiliki dalam menyelesaikan suatu pekerjaan disekolah yang dipimpinnya. 
Tim penilai PKKM di MI Al-Hikmah Cibeusi kali ini adalah Samingan, S.Pd., M.A dan Dra Endang, M.A selaku Pengawas Madrasah sesuai dengan Petunjuk Teknis PKKM, tim penilai kinerja kepala sekolah/madrasah memiliki persyaratan sebagai penilai seperti di bawah ini:

a. Memahami pedoman penilaian dan terlatih melakukan penilaian kinerja.

b. Memiliki keterampilan menggunakan instrumen untuk menghimpun data secara objektif.

c. Memiliki kemampuan mengolah dan menafsirkan data hasil penilaian serta menyusun rekomendasi dari hasil penilaian sebagai input bagi pembuat kebijakan

Menurut tim penilai dan juga pengawas madrasah dengan regulasi yang baru terkait dengan penilaian kinerja kepala madrasah, dapat memberikan dampak positif terhadap peningkatan kompetensi kepala madrasah, sesuai dengan manfaat PKKM dalam Petunjuk Teknis Penilaian Kinerja Kepala Madrasah adalah sebagai berikut:

a. Kepala madrasah dapat mengetahui kelebihan dan kekurangan berdasarkan hasil nilai kinerjanya.

b. Kepala madrasah menjadikan hasil penilaian kinerja sebagai acuan untuk meningkatkan keprofesiannya.

c. Kantor Wilayah Kementerian Agama
Provinsi dan/ atau Kantor Kementerian Agama Kabupaten/ Kota dapat menggunakan hasil penilian kinerja kepala madrasah untuk menghimpun informasi, menentukan kebutuhan peningkatan kompetensi, data profil kinerja kepala madrasah dan bahan pertimbangan penugasan kepala madrasah sesuai kewenangannya.

d. Yayasan/ Lembaga penyelenggara Pendidikan dapat menggunakan hasil penilaian kinerja kepala madrasah sebagai dasar untuk menghimpun informasi, menentukan penimgkatan kompetensi, data profil kinerja kepala madrasah dan bahan pertimbangan penugasan kepala madrasah di Yayasan/Lembaga.

e. Direktorat Guru dan Tenaga Kependidikan Madrasah memperoleh data dan pemetaan mutu kinerja kepala madrasah secara nasional.

Tim penilai melakukan pengamatan dan pencatatan bukti-bukti lain yang ada di lingkungan madrasah yang belum atau tidak dapat disertakan dalam laporan tertulis. Bukti-bukti dapat diidentifikasi melalui pengamatan terhadap kondisi fisik yang ada di lingkungan madrasah atau meminta infomasi dari orang-orang yang relevan yang ada di lingkungan madrasah yaitu siswa, guru, dan komite madrasah. 
Dalam hal penentuan nilai kinerja tim penilai melakukan pengamatan, wawancara dengan warga MI Al-Hikmah Cibeusi setelah bukti-bukti fisik usaha pengembangan madrasahdikumpulkan. Adapun tahapannya adalah sebagai berikut:

1) Penentuan Skor indikator kinerja

Indikator kinerja yang tidak dimiliki oleh madrasah, maka indikator tersebut dikeluarkan dari instrumenpenilaian. Hal ini sesuai dengan pendapat tim penilai bahwa:

"Dalam komponen usaha pengembangan madrasah, ada beberapa indikator yang tidak terpenuhi oleh kepala MI AlHikmah, sehingga saya tidak memberikan nilai, dan membuat catatan agar menjadi rekomendasi untuk perbaikan selanjutnya".

Perangkat administrasi PKKM yang digunakan oleh tim penilai terdiri 3 komponen yang saling menunjang efektivitas pengumpulan data otentik tentang pemenuhan standar kinerja kepala madrasah. Perangkat admknistrasi tersebut adalah sebagai berikut:

\section{a. Data penilaian}

Pelaksanaan PKKM diawali dengan memahami langkahlangkah penilaian, format identitas madrasah, penilai dan kepala madrasah yang dinilai. Data yang terdapat pada format PKKM diisi pada kegiatan awal penilaian oleh penilai. Dokumen tersebut menjadi bukti fisik dalam melaksanakan penilaian, maka di bagian akhir lembar penilaian dibubuhkan tanda tangan penilai dan yang dinilai

\section{b. Instrumen Penilaian Kinerja}

\section{Kepala Madrasah}

Instrumen PKKM terdiri dari instrument penilaian kinerja tahunan dan instrumen penilaian kinerja empat tahunan. Instrumen ini terdiri dari: (1) bagian tugas utama, (2) indicator kinerja, (3). Data kinerja yang diharapkan dan (4). Bukti hasil kinerja dan (5) hasil penilaian

\section{c. Rekapitulasi Hasil Penilaian}

\section{Kinerja}

Untuk memenuhi asas transparansi dan akuntabilitas, maka setelah pelaksanaan penilaian, tim penilai menyerahkan rekapitulasi hasil penilaian yang harus ditandatangani oleh kedua belah pihak. Rekapitulasi hasil penilaian meliputi: (1) Hasil penilaian kinerja tahunan, (2). Rekapitulasi penilaian kinerja tahunan.

Berdasarkan hasil PKKM, maka diperoleh nilai untuk MI Al-hikmah Cibeusi adalah 91, sehingga 
dikategorikan amat baik. Setelah pelaksanaan PKKM di MI Al-Hikmah Cibeusi, kemudian Tim Penilai membuat Laporan Hasil Penilaian Kinerja Tahunan Kepala Madrasah pada MI Al-Hikmah Cibeusi yang diserahkan kepada Kepala Kantor Kementerian Agama Kabupaten Sumedang dengan tembusan kepada ketua Yayasan paling lambat 2 minggu setelah pelaksanaan PKKM di MI Al-Hikmah Cibeusi yang berisi surat pengantar yang dilengkapi dengan hasil PKKM dan surat tugas.

Selanjutnya, setelah PKKM di MI Al-Hikmah Cibeusi, kepala MI Alhikmah Cibeusi mengikuti uji kompetensi yang dilaksanakan di Kemenag Kab. Sumedang. Materi uji kompetensi meliputi: wawasan keislaman dan kebangsaan, pemahaman kompetensi madrasah, portofolio kepala madrasah dan materi substansi yaitu: kepemimpinana, kemampuan pemecahan masalah dan kemampuan pengambilan keputusan. Metode yang digunakan dalam uji kompentensi antara lain: tes tertulis, presentasi, wawancara dan dinamika kelompok. Selanjutnya kepala MI Al- Hikmah Cibeusi dinyatakan lulus ujim kometensi memiliki skor akhir 90.

Berdasarkan uraian tersebut, dapat disimpulkan bahwa pelaksanaan PKKM pada komponen usaha pengembangan madrasah di Madrasah Ibtidaiyah (MI) Al- Hikmah Jatinangor Sumedang telah dilaksanakan.

\section{Pengawasan Penilaian Kinerja} Kepala Madrasah (PKKM) pada komponen usaha pengembangan madrasah di Madrasah Ibtidaiyah (MI) Al-Hikmah

Jatinangor

\section{Sumedang.}

Berdasarkan hasil temuan dan interpretasi, pengawasan PKKM pada komponen usaha pengembangan madrasah di Madrasah Ibtidaiyah (MI) Al- Hikmah Jatinangor Sumedang adalah sebagai berikut:

Pengawasan PKKM dilakukan oleh pengawas MI Kecamatan Jatinangor, hal ini sesuai dengan pendapat Terry bahwa:

"Controlling can be defined as the process of determining what is to accomplished, that is the standard, what is being accomplished. That is the performance, evaluating the performance, and if the necessary applying corrective measure so that performance takes place according to plans, that is conformity with the standard. (Pengawasan dapat dirumuskan sebagai proses penentuan apa yang harus dicapai yaitu standard, apa yang sedang dilakukan yaitu pelaksanaan, menilai pelaksanaan, dan bilaman perlu melakukan perbaikanperbaikan, sehingga pelaksanaan sesuai dengan rencana, yaitu selaras dengan standard (ukuran)". 
Adapun tujuan dari pengawasan adalah untuk memastikan bahwa pelaksanaan PKKM sesuai dengan prosedur dan mekanisme yang berlaku dan Bentuk pengawasan pada PKKM adalah adanya pelaporan dan evaluasi PKKM, bedasarkan wawancara kepada pengawas MI dapat diketahui bahwa bentuk pengawasan meliputi

a. Pemantauan dan evaluasi terhadap pelaksanaan penilaian kinerja kepala madrasah dilakukan secara berjenjang sesuai dengan kewenangannya untuk menjamin bahwa pelaksanaan penilian kinerja sesuai dengan ketentuan yang berlaku.

b. Kanwil Kementerian Agama Provinsi wajib membuat laporan PKKM di wilayahnya secara periodic setiap tahun. Laporan tersebut disampaikan kepada Direktorat Guru dan Tenaga Kependidikan Madrasah.

Hal tersebut sesuai dengan metoda pengawasan menurut Ya'qub, H (1964) merupakan masalah, oleh karena inti pengawasan adalah pengkuran (measurement) yang pada hakekatnya merupakan pengambilan keputusan (decision making) dan dengan demikian merupakan suatu pemikiran rasional. Obyek pengawasan yang harus diukur itu dapat diklasifikasikan menjadi dua golongan, yaitu: keseluruhan dan bagianbagiannya.

Selanjutnya, jika terjadi pelanggaran maka akan ada sanksi dari Direktorat Jenderal Pendidikan Islam kepada pihak yang melakukan pelanggaran berupa teguran tertulis. Jika teguran tersebut tidak ditindaklanjuti, maka Dirjen Pendis akan meminta bantuan Irjen Kemenaguntuk menyelesaikan penyimpangan terhdapa proses pelaksanaan PKKM.

Dalam usaha pengemabangan madrasah kepala madrasah juga berperan aktif demi menjadikan lembaga pendidikanya menjadi lebih favorit. Kegiatan pengawasan yang difokuskan pada aspek-aspek yang berada di seluruh sekolah, di samping itu juga menegaskan tentang menjaga nama baik sekolah dan kinerja yang berada di sekolah secara keseluruhan.

Dalam hal ini kepala madrasah melakukan kegitan pengawasan dalam bidang lembaga seperti program penerimaan peserta didik, pengembangan kurikulum sekolah, pembuatan jadwal, pengelolaan sarana prasana dan juga hubungan kerja sama antara wali murid.

Kemudian terkait dengan pengawasan bidang lembaga di MI ini juga sudah di laksanakan sebagaimana mestinya walaupun belum berjalan dengan maksimal akan tetapi tetap pengawasan sangat 
berperan penting demi meningkatnya kualitas madrasah sendiri.

Dengan adanya hasil yang diperoleh dari wawancara dengan kepala madrasah menerangkan bahwa pengawasan bidang lembaga sudah diupayakan namun masih banyak kekurangan karena tidak berperan aktif dalam lembaga tersebut. Pengawasan dalam bidang lembaga merupakan kegiatan dimana untuk meningkatkan nama baik sekolah atau kinerja sekolah secara keseluruhan sehingga dari pihak pimpinan Muhammadiyah Kabupaten Sumedang juga mempunyai hak dalam membuat kualitas yang unggul tentang madrasah ini.

Pengawasan lembaga yang ada di MI ini sudah berjalan dengan cukup baik karena pentingnya peranan pimpinan ranting atau majelis pendidikan dasar menengah di suatu madrasah menjadi hal yang penting untuk ditingkatkan lagi, karena dengan adanya pengawasan lembaga maka semua program sekolah akan terlihat kekurangan dan kelebihan suatu lembaga atau madrasah sehingga peran dari pimpinan ranting adalah membimbing, mengarahkan dan membina Kepala Madrasah, guru, karyawan yang tujuannya adalah meningkatkan nama baik sekolah dan kinerja sekolah secara keseluruhan".

Pengawasan PKKM di MI Al-Hikmah Cibeusi dilakukan oleh yayasan dan pengawas MI Kecamatan Jatinangor, meskipun tidak dilakukan secara intens. Pengawas hanya memberikan instrument PKKM dan kepala MI Al-Hikmah Cibeusi beserta guru-guru bermusyawarah untuk memahami hal-hal apa saja yang dilengkapi jika tidak ada yang dipahami. Setelah proses persiapan kurang lebih 1 bulan, baru ada pengawasan yayasan untuk mengetahui sejauh mana persiapan yang telah dilakukan. Kemudian saat jadwal PKKM mendekati hari $\mathrm{H}$, barulah pengawas mengecek hal-hal yang diperlukan untuk PKKM.

Pentingnya pengawasan demi meningkatakan kualitas guru dan juga karyawan, tidak hanya pengawasan akademik saja tetapi dalam bidang lembaga juga seharusnya tetap dilaksanakan walaupun di MI masih belum maksimal dalam pelaksanaanya namun pihak madrasah tetap mengupayakan kegiatan tersebut sesuai dengan kemampuan yang ada.

Kepala Madrasah MI Al-Hikmah Jatinangor Sumedang dalam melaksanakan supervisi lembaga sudah cukup baik terutama dalam meningkatkan mutu pendidikan baik out put dan input, sesuai dengan pendapat Terry mengemukakan bahwa:

"Controlling can be defined as the process of determining what is to accomplished, that is the standard, what is being accomplished. That is the 
performance, evaluating the performance, and if the necessary applying corrective measure so that performance takes place according to plans, that is conformity with the standard. (Pengawasan dapat dirumuskan sebagai proses penentuan apa yang harus dicapai yaitu standard, apa yang sedang dilakukan yaitu pelaksanaan, menilai pelaksanaan, dan bilaman perlu melakukan perbaikanperbaikan, sehingga pelaksanaan sesuai dengan rencana, yaitu selaras dengan standard (ukuran)".

Dalam sebuah lembaga pendidikan sangatlah penting dalam pelaksanaan supervisi lembaga sehingga lembaga tersebut dapat lebih baik kedepannya dan bisa menarik perhatian kepada masyarakat untuk menyekolahkan anaknya di MI AlHikmah Jatinangor Sumedang.

Selain hal itu kinerja supervisi kepala madrasah dapat berjalan baik dengan pelaksanaan supervisi yang ada dan juga menegaskan bahwa tujuan dari supervisi sendiri adalah untuk menjadikan guru dan karyawan lebih berkualitas lagi untuk kedepannya, oleh karena itu penulis dapat menerangkan bahwa kinerja supervisi di MI Muhammadiyah sudah berjalan dalam ketiga bidang supervisi yang meliputi supervisi bidang akademik, bidang administrasi dan juga dalam bidang lembaga. Berdasarkan uraian tersebut dapat disimpulkan bahwa pengawasan PKKM pada komponen usaha pengembangan madrasah di Madrasah Ibtidaiyah (MI) AlHikmah Jatinangor Sumedang belum maksimal dilakukan oleh pengawas.

\section{Kesimpulan [12 pt. Arial Bold]}

Secara umum, penelitian ini telah mendapat gambaran tentang Manajemen Penilaian Kinerja Kepala Madrasah (PKKM) pada komponen usaha pengembangan madrasah di Madrasah Ibtidaiyah (MI) Al-Hikmah Jatinangor Sumedang, yakni Kepala MI Al-Hikmah Jatinangor Sumedang telah melakukan perencanaan, pengorganisasian, pelaksanaan PKKM yang diawasi oleh pengawas MI Kecamatan Jatinangor

\section{Daftar Pustaka}

Akdon, (2009). Strategic Management. Bandung: Alfabeta.

Hasibuan, M (2017). Manajemen Sumber Daya Manusia (Cet-17) Jakarta: PT Bumi Aksara.

Holi, (2012). How Should An Effective Performance Appraisal Be: Efl Teacher's Perspective? International Journal of Applied Linguistics and English Literature, Vol I, No 7. 9

Husein, (2008). Strategi Management In Action (Konsep, Teori, dan Teknik Menganalisis Manajajemen Strategis), Penerbit PT. Gramedia Pustaka Utama, Jakarta

Jensen B, and Reichl, J. (2011). Better Teacher Appraisal and Feddback: 
Improving Performance. Melbourne: Grattan Institute.

Karwati,dkk (2012). Kinerja dan Profesionalisme Kepala Sekolah. Bandung, Alfabeta.

Kemendikbud (2012). Pedoman Penilaian Kinerja Kepala Sekolah. Lampiran Keputusan Dirjen Pendis Nomor tahun 2019 Mangkunegara,

A.A. (2017). Manajemen Sumberdaya Manusia Perusahaan. (Cet- 14).Bandung: PT. Remaja Rosdakarya.

Moleong, J.L (2019). Metodologi Penelitian (cet-39). Bandung: Rosdakarya.

Mulyasa. E. (2015). Menjadi Guru Profesional. Bandung: Rosdakarya.

Ranupandojo, dkk (2002), Manajemen Personalia, Yogyakarta: BPFE.

Simamora,H. (2005). Manajemen Sumber Daya Manusia. Yogyakarta:

STIE YKPN. 2005).. Sondang P. (2010). Manajemen Sumber Daya Manusia, Bumi Aksara, Jakarta

Suhardiman, (2012).Studi Pengembangan Kepala Sekolah Konsep dan Aplikasi, Jakarta:PT Rineka Cipta.

Sugiyono, (2016). Metode Penelitian Kombinasi. (Cet-8) Bandung: Alfabeta.

Sukarna. (2011). Dasar-dasar Manajemen. Bandung:

Mandar Maju Terry, (2006). PrinsipPrinsip Manajemen. Jakarta: Bumi Aksara, 2006 UU No. 20/2003 tentang Sisdiknas

Ya'qub, H (1984). Menuju Keberhasilan Manajemen dan Kepemimpinan. Bandung: CV Diponegoro. 